\title{
ANALISIS PEMELIHARAAN SALURAN DISTRIBUSI 20 KV DALAM KEADAAN BERTEGANGAN DI RAYON KUTA
}

\author{
I N Tidi Wahyunitya $\mathbf{S}^{1}$, A A Gede Maharta Pemayun ${ }^{2}$, Antonius lbi Weking ${ }^{3}$ \\ Jurusan Teknik Elektro dan Komputer, Fakultas Teknik, Universitas Udayana \\ Email: tidi.wahyu@gmail.com ${ }^{\underline{1}}$, maharta@unud.ac.id ${ }^{2}, \underline{\text { tony@unud.ac.id }}^{3}$
}

\begin{abstract}
ABSTRAK
Pemadaman yang dilakukan untuk pekerjaan pemeliharaan, menyebabkan kerugian bagi konsumen dan PLN. Kerugian yang dialami adalah diskontinuitas pelayanan penyaluran energi listrik dan kWH yang diproduksi oleh PLN tidak dapat tersalurkan, maka dari itu perlu dilakukan pemeliharaan dalam keadaan bertegangan (PDKB). Sebelum melakukan pekerjaan bertegangan, perlu dilakukan studi kelayakan investasi peralatan bertegangan dari aspek ekonomis. Metode yang digunakan pada penelitian ini yaitu Net Present Value (NPV), Internal Rate Of Return (IRR) dan Net Benefit Cost Ratio (NET B/C), sehingga dapat diketahui besar nilai tingkat keuntungan melalui pemeliharaan bertegangan. Pemeliharaan dalam keadaan bertegangan (PDKB) di PT PLN (Persero) Rayon Kuta dapat menyelamatkan rupiah kWh sebesar Rp.8.941.763.694/ tahun. Sistem Average Interruption Duration Index (SAIDI) yang ditekan adalah 991,812243 menit/ pelanggan, untuk System Average Interruption Frequency Index (SAIFI) adalah 14.60000046 kali/ pelanggan, Net Present Value bernilai positif sebesar Rp.27.347.312.169, Internal Rate Of Return diperoleh sebesar 18,111\%, sedangkan Net Benefit Cost Ratio diperoleh 6,462 lebih besar dari 1. Dengan demikian pekerjaan pemeliharaan bertegangan secara teknis dan ekonomis sangat layak untuk dilaksanakan.
\end{abstract}

Kata Kunci : PDKB, kWh jual, SAIDI, SAIFI, investasi

\section{ABSTRACT}

Power outages for maintenance work may result in the customers' losses and for the State Owned-Power Plant (PLN) itself. The losses are the discontinuity of power distribution or loss of supply for which PLN receives customer complaints or financially penalized. Therefore, a live-line maintenance (PDKB) is needed to overcome the loss of supply. Before doing the liveline maintenance, investment feasibility studies need to be done on the tools for live-line maintenance from the economical aspects. The method used in this research is the Net Present Value (NPV), Internal Rate Of Return (IRR) and Net Benefit Cost Ratio (NET B / C), so it can be determined the total value for the rate of profit through the live-line maintenance. The live-line maintenance (PDKB) at PT PLN (Persero) of Kuta region can save money of Rp.8.941.763.694 $k W h$ / year. Sistem Average Interruption Duration Index (SAIDI) that can be saved was 991.812243 minutes / customer, for System Average Interruption Frequency Index (SAIFI) was 14.60000046 times / customers, Net Present Value was positive of Rp.27.347.312.169, Internal Rate Of Return obtained was 18.111\%, while Net Benefit Cost Ratio was 6.462 greater than 1. Therefore, the live-line maintenance work is technically and economically feasible.

Keywords: live-line maintenance, $k W h$ selling rate, SAIDI, SAIFI, investment

\section{PENDAHULUAN}

PT. PLN (persero) akan selalu mengupayakan untuk pemeliharaan peralatan jaringan yang ada pada jaringan distribusi tenaga listrik agar dapat beroprasi dengan optimal. untuk menjamin keandalan peralatan di jaringan distribusi tenaga listrik pada suatu penyulang. Salah satu persoalannya adalah masih seringnya dilakukan pemadaman untuk pekerjaan pemeliharaan jaringan. Teknik pekerjaan seperti ini merupakan masalah, karena menyebabkan kerugian bagi konsumen dan perusahaan listrik itu sendiri. Bagi konsumen kerugian yang ditimbulkan adalah diskontinuitasnya pelayanan penyaluran tenaga listrik, sedangkan bagi PLN kWh yang diproduksi tidak bisa tersalurkan. 
Solusi untuk menekan adanya pemadaman guna meningkatkan SAIDI dan SAIFI, maka PLN dapat melakukan pemeliharaan jaringan distribusi saluran udara $20 \mathrm{kv}$ dalam keadaan bertegangan. Dengan demikian PLN dapat meningkatkan mutu pelayanan dan $\mathrm{kWh}$ jual serta dapat mendukung program yang telah dicanangkan oleh PLN. Program Generator On Sale (GOS). Bertujuan untuk meningkatkan penjualan listrik 10\% [1].

Rumusan masalahnya adalah berapa besar jumlah kWh yang dapat terselamatkan dengan adanya PDKB, berapa besar nilai keandalan pemeliharaan saat bertegangan dilihat dari SAIDI dan SAIFI, dan analisis investasi peralatan kegiatan pemeliharaan bertegangan. Ruang lingkup penelitian ini hanya mencakup wilayah PLN (Persero) Rayon Kuta.

\section{KAJIAN PUSTAKA}

\section{$2.1 \mathrm{kWh}$ Jual}

kWh jual adalah energi listrik yang terjual atau yang didistribusikan oleh PLN kepada konsumen. Dalam penelitian ini yang dimaksud dengan kWh jual adalah saving kWh atau kWh terselamatkan oleh team PDKB. Besarnya saving kWh yang dapat diselamatkan oleh PDKB dapat dihitung dengan persamaan (1).

Saving kWh PDKB $=$ Beban $x \sqrt{3} \times 20 k V x$ $\cos \theta \times t \times$ jumlah titik

Sedangkan untuk perhitungan rupiah kWh dihitung dengan persamaan (2).

Rupiah kWh PDKB = Beban $x \sqrt{3} \times 20 k V x$

$\cos \theta \times t \times$ jumlah titik $\times \mathrm{Rp} / \mathrm{kWh}$

Keterangan :

Beban adalah Beban Penyulang dalam Ampere

$\cos \theta$ adalah 0,85 standar PLN Bali

$20 \mathrm{kV}$ adalah Tegangan Penyulang

$t$ adalah Standar waktu PDKB

Jumlah titik adalah Banyaknya titik kerja

\subsection{SAIDI PDKB}

Sistem Average Interruption Duration Index (SAIDI) didefinisikan sebagai nilai ratarata dari lamanya kegagalan untuk setiap konsumen selama satu tahun [2].

Cara menghitung SAIDI yang dipengaruhi oleh kinerja PDKB adalah seperti persamaan (3).

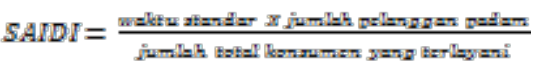

\subsection{SAIFI PDKB}

System Average Interruption Frequency Index (SAIFI) merupakan Indeks ini didefinisikan sebagai jumlah rata-rata kegagalan yang terjadi per pelanggan yang dila- yani oleh sistem persatuan waktu (umumnya pertahun). Cara menghitung SAIFI yang dipengaruhi oleh kinerja PDKB adalah seperti persamaan (4)[3].

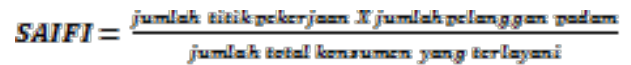

\subsection{Kriteria penilaian investasi}

Di dalam menerima/ menolak suatu investasi dapat dipergunakan beberapa kriteria yaitu :

\section{Metode Net Present Value}

Metode NPV Secara matematis dapat ditulis pada persamaan berikut(5)[4]. :

$$
\sum_{t=0}^{n} \frac{A t}{(1+i)^{t}}-I O
$$

Keterangan:

I adalah Discount rate yang digunakan

At adalah Arus kas tahunan setelah pajak dalam periode tahunan $t$

$t$ adalah jumlah tahun analisa

IO adalah jumlah investasi (pengeluaran awal)

$n \quad$ adalah periode yang terakhir dari arus kas yang diharapkan

\section{Metode Internal Rate of Return (IRR)}

Internal Rate of Return (IRR). Secara Matematis pada persamaan (6).

$$
\sum_{t=0}^{n} \frac{B t}{(1+i)^{n}}=\sum_{t=0}^{n} \frac{C t}{(1+i)^{n}}
$$

Keterangan :

$i$ adalah Discount rate yang digunakan

$B t$ adalah Jumlah benefit dalam periode tahun $t$

$t$ adalah Jumlah tahun analisa

Ct adalah Jumlah cost dalam periode tahun $t$

$n$ adalah Periode yang terakhir dari arus kas yang diharapkan

Untuk mendapatkan nilai internal rate of return digunakan persamaan (7) [5].

$$
r=P 1-C 1 \frac{P Z-P 1}{C 2-C 1}
$$

Keterangan :

$r$ adalah internal rate of return yang dicari

$P 1$ adalah tingkat bunga ke 1

$P 2$ adalah tingkat bunga ke 2

C1 adalah net present value ke 1

C2 adalah net present value ke 2

Apabila rate of return yang diinginkan lebih kecil dari internal rate of return yang sebenarnya, maka usul investasi tersebut dapat diterima.

\section{Metode Net Benefit Cost Ratio}

Net Benefit Cost Ratio merupakan angka perbandingan antara jumlah present value 
yang positif (sebagai pembilang) dengan jumlah present value negative (sebagai penyebut).

Net Benefit Cost Ratio dapat dihitung dengan menggunakan persamaan (8).

$$
N e t B / C=\frac{\sum_{t=0}^{n} \frac{B t-c t}{(1+1)^{t}}}{\sum_{t=0}^{n} \frac{(t-B t}{(1+1)^{t}}}
$$

Keterangan :

$B t$ adalah Benefit untuk periode $t$

$C t$ adalah Biaya untuk periode $t$

I adalah Tingkat bunga/discount rate yang dipergunakan

$N$ adalah Periode yang terakhir dimana aliran kas digunakan

Kriteria investasi tersebut diterima apabila Net $B / C>1$ dan ditolak apabila perhitungan Net $B / C<1$.

\subsection{Penghasilan kena Pajak}

Menurut undang-undang perpajakan no. 10 tahun 1994 pasal 17 ayat 1 . Tarif pajak yang ditetapkan atas penghasilan kena pajak adalah seperti Tabel 1.

Tabel 1. Tarif Pajak

\begin{tabular}{|c|c|}
\hline Penghasilan kena pajak (PKP) & Tarif pajak \\
\hline$<$ Rp. 25.000.000.- & $10 \%$ \\
\hline Rp. 25.000.000,- s/d Rp. 50.000.000,- & $15 \%$ \\
\hline >Rp. 50.000.000,- & $30 \%$ \\
\hline
\end{tabular}

\section{METODE PENELITIAN}

\subsection{Sumber dan Jenis Data}

Sumber data dalam penelitian ini diperoleh dari PT. PLN (Persero) Rayon Kuta dan Team PDKB Bali Selatan dan seluruhnya menggunakan data sekunder.

\subsection{Analisis Data}

Penelitian ini dilakukan dalam beberapa tahapan, diantaranya :

1. Menghitung jumlah nilai kWh tak terjual yang dapat diselamatkan dengan kegiatan PDKB.

2. Mencari besar keandalan pemeliharaan dalam keadaan bertegangan dilihat dari SAIDI dan SAIFI.

3. Studi analisis investasi kegiatan pemeliharaan saluran distribusi dalam keadaan bertegangan.

\section{HASIL DAN PEMBAHASAN}

\subsection{Perhitungan Kwh Jual, SAIDI DAN SAIFI}

Pekerjaan penyamaan phasa lokasi di Desa Sawangan, Nusa Dua dengan data diambil pada tanggal 27-01-2015 adalah sebagai berikut:

Penyulang Sawangan
Beban : 39 Ampere

Jumlah pelanggan padam : 41

Durasi : 1 jam

Jumlah pelanggan penyulang Sawangan : 528883 pelanggan

Rp/kWh bulan januari : 1.496

SAVING KWH,

$$
\begin{aligned}
& =\text { Beban } \times \sqrt{3} \times 20 \mathrm{KV} \times \cos \theta \times \mathrm{t} \times \\
& \quad \text { jumlah } \\
& =1148,34
\end{aligned}
$$

Rp kWh terselamatkan,

$$
\mathrm{Rp}=\text { Saving kWh } \mathrm{x} \text { harga } \mathrm{kWh} \text { bulan }
$$$$
=1717974,057
$$

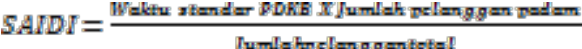

$$
\begin{aligned}
& =\frac{60 \times 41}{528883}=\frac{2460}{528883}=0,0046 \mathrm{Menit} / \text { pelanggan }
\end{aligned}
$$

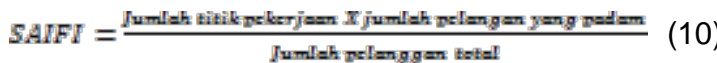

$$
\begin{aligned}
& =\frac{1 \times 41}{528883}=0,000077 \mathrm{kali} / \text { pelanggan }
\end{aligned}
$$

Total jumlah kWh dan Rupiah kWh yang dapat diselamatkan dengan menggunakan PDKB selama satu tahun adalah sebesar 6938693.953 kWh dan Rp.8941763694 untuk saidi dan saifi yang dapat ditekan dengan menggunakan PDKB sebesar 991.812243 untuk SAIDI dan 14.60000046 untuk SAIFI.

\subsection{Aliran Kas}

Data yang dipergunakan untuk menghitungan aliran kas masuk yaitu.

1. Jumlah perkiraan investasi Investasi yang diperlukan adalah yaitu : Investasi peralatan = Rp. 3.556.355.000 Investasi kendaraan = Rp.1.450.000.000 total investasi Rp.5.006.355.000,

2. Jumlah penerimaan kotor = Rp.8.941.763.694 per tahun,

3. Tingkat bunga uang pengembalian $=30 \%$ per tahun,

4. Umur ekonomis investasi $=20$ tahun.

Dengan penyusutan 5\% pertahun dengan metode saldo menurun. Besarnya depresiasi pertahun dan nilai residu (salvage value) dapat diliat pada Tabel 2.
Tabel 2. Depresiasi investasi

\begin{tabular}{|c|c|c|}
\hline $\begin{array}{c}\text { Akhir } \\
\text { Tahun } \\
\text { ke }\end{array}$ & Depresiasi (Rp) & $\begin{array}{c}\text { Nilai Buku Aktiva } \\
\text { (Rp) }\end{array}$ \\
\hline 0 & & $5.006 .355 .000,00$ \\
\hline 1 & $250.317 .750,00$ & $4.756 .037 .250,00$ \\
\hline 2 & $237.801 .862,50$ & $4.518 .235 .387,50$ \\
\hline 3 & $225.911 .769,37$ & $4.292 .323 .618,13$ \\
\hline 4 & $214.616 .180,90$ & $4.077 .707 .437,23$ \\
\hline
\end{tabular}




\begin{tabular}{|c|l|l|}
5 & $203.885 .371,86$ & $3.873 .822 .065,37$ \\
\hline 6 & $193.691 .103,29$ & $3.680 .130 .962,11$ \\
\hline 7 & $184.006 .548,10$ & $3.496 .124 .414,01$ \\
\hline 8 & $174.806 .220,70$ & $3.321 .318 .193,31$ \\
\hline 9 & $166.065 .909,66$ & $3.155 .252 .283,65$ \\
\hline 10 & $157.762 .614,18$ & $2.997 .489 .669,47$ \\
\hline 11 & $149.874 .483,47$ & $2.847 .615 .186,00$ \\
\hline 12 & $142.380 .759,30$ & $2.705 .234 .426,70$ \\
\hline 13 & $135.261 .721,33$ & $2.569 .972 .705,37$ \\
\hline 14 & $128.498 .635,26$ & $2.441 .474 .070,11$ \\
\hline 15 & $122.073 .703,50$ & $2.319 .400 .366,61$ \\
\hline 16 & $115.970 .018,33$ & $2.203 .430 .348,28$ \\
\hline 17 & $110.171 .517,41$ & $2.093 .258 .830,87$ \\
\hline 18 & $104.662 .941,54$ & $1.988 .595 .889,33$ \\
\hline 19 & $99.429 .794,460$ & $1.889 .166 .094,87$ \\
\hline 20 & $94.458 .304,740$ & $1.794 .707 .790,13$ \\
\hline 21 & $89.735 .389,500$ & $1.704 .972 .400,63$ \\
\hline & $\begin{array}{l}\text { Salvage value } \\
\text { (nilai residu) }\end{array}$ & $1.704 .972,400,63$ \\
\hline
\end{tabular}

5. Perkiraan Biaya Operasional

Adapun biaya operasional tahun ke-1 menyangkut biaya-biaya :

A. Ongkos tenaga kerja langsung yang dibutuhkan sebagai berikut :

a. Pembantu (helper)

Untuk pembantu gaji kerja satu bulan Rp.4.800.000. sehingga gaji dalam 1 tahun : Rp.57.600.000

b. Teknisi

Untuk teknisi gaji kerja satu bulan Rp.4.800.000. sehingga gaji dalam 1 tahun : Rp.57.600.000

c. Pengawas Untuk teknisi gaji kerja satu bulan Rp.9.900.000sehingga gaji dalam 1 tahun : Rp.118.800.000

B. Biaya Transport

Biaya transport meliputi gaji supir, biaya bahan bakar, biaya pemeliharaan kendaraan.

a. Gaji supir

Gaji supir 1 bulan Rp.3.000.000. sehingga gaji dalam 1 tahun Rp.36.000.000

b. Biaya bahan bakar

pembelian bahan bakar 1 bulan Rp.3.000.000. dalam 1 tahun adalah Rp.36.000.000

c. Biaya pemeliharaan kendaraan

Pemeliharaan kendaraan dalam 1 bulan Rp.400.000. sehingga dalam 1 tahun Rp.4.800.000

C. Biaya pemeliharaan peralatan

Besarnya biaya pemeliharaan bertegangan sebesar : Rp.87.318.000

Diasumsikan biaya-biaya akan mengalami kenaikkan sebesar $5 \%$ setiap tahunnya. Jadi aliran dana masuk untuk tahun pertama dapat dihitung dengan data-data sebagai berikut :
Pendapatan kotor sebesar Rp. 8.941.763.694. Biaya operasional yang dipergunakan berdasarkan tabel 3 Tahun pertama yaitu sebesar Rp.648.435.750

1. Pendapatan bersih sebelum pajak penghasilan (pph)

Pendapatan kotor = Rp. 8.941.763.694

Biaya (cost) = Rp. 648.435.750

Jadi pendapatan bersih sebelum pajak tahun pertama adalah:

Pendapatan bersih sebelum pajak

$($ EBT $)=$ Pendapat kotor - Biaya

$\mathrm{EBT}=8.941 .763 .694-648.435 .750$

= Rp. 8.293.327.944

2. Pendapatan bersih setelah pajak penghasilan (EAT)

Pendapat bersih setelah pajak

$(E A T)=E B T-($ EBT $\times \%$ Pajak $)$

Pendapatan Bersih sebelum pajak (EBT) adalah Rp. 8.293.327.944

Jadi total pajak penghasilan yang harus dibayar untuk pendapatan sebesar Rp.8.293.327.944

Perhitungan berdasarkan Undang-Undang No.10 tahun 1994 pasal 17 (ayat 1) sebagai berikut :

Perhitungan kena pajak penghasilan tahun pertama Rp. 8.293.327.944

Penghasilan sampai 50 juta pajak 5\%

$50.000 .000 \times 5 \%=2.500 .000$

Penghasilan diatas 50 juta sampai dengan 250 juta pajak $15 \%$

$250.000 .000 \times 15 \%=37.500 .000$

Penghasilan diatas 250 juta sampai dengan 500 juta pajak $25 \%$

$500.000 .000 \times 25 \%=125.000 .000$

Penghasilan diatas 500 juta pajak $30 \%$

7.493.327.944 x 30\% = 2.247.998.383, 2

Jadi besar pajak penghasilan yang harus dibayar pada tahun pertama sebesar:

$2.500 .000+37.500 .000+125.000 .000+$

$2.247 .998 .383,2=2.412 .998 .383,2$

Jadi pendapatan bersih setelah pajak penghasilan (EAT) adalah :

EAT = EBT $-($ EBT $x \%$ Pajak $)$

EAT $=8.293 .327 .944-2.412 .998 .383,2$

$=$ Rp. 5.880.329.561

3. Aliran kas masuk atau proceeds untuk periode ke 1

Aliran kas masuk = penghasilan bersih setelah pph (EAT) + Penyusutan

= Rp. 5.880.329.561 + Rp. 250.317.750

$=$ Rp. 6.130.647.311

Analisis Net Present Value

Untuk menghitung present value dari aliran kas investasi peralatan bertegangan digunakan discount factor (DF) $18 \%$. Untuk 
menghitung Net Present Value dipergunakan persamaan (11).

$$
N P V=\sum_{t=0}^{n} \frac{A t}{(1+i)^{t}}+\frac{s}{(1+i)^{t}}
$$

Investasi dapat diterima apabila $\mathrm{Net}$ Present Value nya positif dan ditolak apabila Net Present Value nya Negatif.

Untuk perhitungan NPV atas dasar discount rate $18 \%$ dapat dilihat pada Tabel 3 .

Tabel 3. Perhitungan N.P.V untuk investasi pemeliharaan bertegangan

\begin{tabular}{|c|c|c|c|}
\hline & $\begin{array}{c}\text { Aliran kas } \\
\text { Masuk atau } \\
\text { Proceeds }\end{array}$ & $\begin{array}{c}\text { Faktor } \\
\text { Bunga (P/F } \\
\text { i\% ,n) }\end{array}$ & $\begin{array}{c}\text { Nekarang (P V } \\
\text { ) dari } \\
\text { Proceeds }\end{array}$ \\
\cline { 2 - 4 } 0 & $\mathbf{\text { Rp) }}$ & $\mathbf{i = 1 8 \%}$ & $\mathbf{\text { Rp) }}$ \\
\hline 1 & 5006355000 & 1 & 5006355000 \\
\hline 2 & 6130647311 & 0.8475 & 5195723596 \\
\hline 3 & 6094760550 & 0.6086 & 3709271271 \\
\hline 4 & 6076009495 & 0.5158 & 3134005698 \\
\hline 5 & 6056659755 & 0.4371 & 2647365979 \\
\hline 6 & 6036664453 & 0.3704 & 2235980513 \\
\hline 7 & 6015975213 & 0.3139 & 1888414619 \\
\hline 8 & 5994542048 & 0.2660 & 1594548185 \\
\hline 9 & 5972313234 & 0.2255 & 1346756634 \\
\hline 10 & 5949235189 & 0.1911 & 1136898845 \\
\hline 11 & 5925252341 & 0.1619 & 959298354,0 \\
\hline 12 & 5900306994 & 0.1372 & 809522119.6 \\
\hline 13 & 5874339192 & 0.1163 & 683185648,0 \\
\hline 14 & 5847286570 & 0.0985 & 575957727.1 \\
\hline 15 & 5819084211 & 0.0835 & 485893531.6 \\
\hline 16 & 5789664482 & 0.0708 & 409908245.3 \\
\hline 17 & 5758956876 & 0.0600 & 345537412.6 \\
\hline 18 & 5726887845 & 0.0508 & 290925902.5 \\
\hline 19 & 5693380619 & 0.0431 & 245384704.7 \\
\hline 20 & 5658355027 & 0.0365 & 206529958.5 \\
\hline & PV dari Proceeds & 32291435677 \\
\hline
\end{tabular}

Jadi nilai sekarang Neto atau nilai sekarang bersih (Net Present Value) adalah sebagai berikut :

P.V dari Proceeds (dari Tabel 3 )

$$
N P V=\Sigma_{t=1}^{n=20} \frac{A t}{(1+i)^{t}}=R p .32 .291 .435 .677
$$

Besarnya nilai residu dari Tabel 4 adalah sebesar Rp.1.704.972.400,63

$$
\begin{aligned}
& \quad \text { P.V dari Nilai Residu (S) } \\
& =\frac{S}{(1+i)^{t}} \text { atau } \mathrm{S}(\mathrm{P} / \mathrm{F}, 18 \%, 20) \\
& =\text { Rp. } 62.231 .492,62 \\
& \text { P.V dari Investasi }
\end{aligned}
$$$$
=\sum_{t=0}^{n=0} \frac{A t}{(1+i)^{t}}=R p \cdot 5 \cdot 006 \cdot 355.000
$$

N.P.V = PV dari proceeds + PV dari nilai residu - PV dari investasi

$=\sum_{t=1}^{n=20} \frac{A t}{(1+i)^{t}}+\frac{S}{(1+i)^{t}}-\sum_{t=0}^{n=0} \frac{A t}{(1+i)^{t}}$

$=\mathrm{Rp} \cdot 27.347 .312 .169$

Jadi Net Present Value sebesar Rp. 27.347.312.169 berarti investasi untuk pemeliharaan dalam keadaan bertegangan memberikan keuntungan.

4.4 Analisis Laju Pengembalian (Internal Rate of Return)

Menghitung Net Present Value di pergunakan persamaan (14).

$$
N P V=\sum_{t=0}^{n} \frac{A t}{(1+i)^{r}}+\frac{s}{(1+i)^{r}}
$$

Untuk proses interpolasi menggunakan persamaan (15).

$$
r=P 1-C 1 \frac{P 2-P 1}{C 2-C 1}
$$

Internal rate of return dapat dicari dengan menggunakan perhitungan Net Present Value atas tingkat bunga $18 \%$ dan $19 \%$ dapat dilihat pada Tabel 4.

Tabel 4. Perhitungan PV atas dasar tingkat $18 \%$ dan $19 \%$

\begin{tabular}{|c|c|c|c|c|c|}
\hline \multirow{2}{*}{ Thn } & \multirow{2}{*}{ Proceeds } & \multicolumn{2}{|c|}{ Tingkat Bungaa 18\% } & \multicolumn{2}{c|}{ Tingkat Bunga 19\% } \\
\cline { 3 - 6 } & $\begin{array}{c}\text { Faktor } \\
\text { Bunga }\end{array}$ & $\begin{array}{c}\text { PV Dari } \\
\text { Proceeds }\end{array}$ & $\begin{array}{c}\text { Faktor } \\
\text { Bunga }\end{array}$ & $\begin{array}{c}\text { PV Dari } \\
\text { Proceeds }\end{array}$ \\
\cline { 2 - 6 } & $\mathbf{( R p )}$ & $\begin{array}{c}\text { (P/F } \\
\text { i\%,n) }\end{array}$ & $\mathbf{( R p )}$ & $\begin{array}{c}\text { (P/F } \\
\text {,i\%,n) }\end{array}$ & (Rp) \\
\hline 0 & 5006355000 & 1 & 5006355000 & 1 & 5006355000 \\
\hline 1 & 6130647311 & 0.8457 & 5195723596 & 0.8403 & 5151582935 \\
\hline 2 & 6112958414 & 0.7182 & 4390326733 & 0.7062 & 4316971232 \\
\hline 3 & 6094760550 & 0.6086 & 3709271271 & 0.5934 & 3616630910 \\
\hline 4 & 6076009495 & 0.5158 & 3134005698 & 0.4987 & 3030105935 \\
\hline 5 & 6056659755 & 0.4371 & 2647365979 & 0.4190 & 2537740437 \\
\hline 6 & 6036664453 & 0.3704 & 2235980513 & 0.3521 & 2125509554 \\
\hline 7 & 6015975213 & 0.3139 & 1888414619 & 0.2959 & 1780127066 \\
\hline 8 & 5994542048 & 0.2660 & 1594548185 & 0.2487 & 1490842607 \\
\hline 9 & 5972313234 & 0.2255 & 1346756634 & 0.2090 & 1248213466 \\
\hline 10 & 5949235189 & 0.1911 & 1136898845 & 0.1756 & 1044685699 \\
\hline 11 & 5925252341 & 0.1619 & 959298354,0 & 0.1476 & 874567245.5 \\
\hline 12 & 5900306994 & 0.1372 & 809522119.6 & 0.1240 & 731638067.3 \\
\hline 13 & 5874339192 & 0.1163 & 683185648,0 & 0.1042 & 612106143.8 \\
\hline 14 & 5847286570 & 0.0985 & 575957727.1 & 0.0876 & 512222303.5 \\
\hline 15 & 5819084211 & 0.0835 & 485893531.6 & 0.0736 & 428284597.9 \\
\hline 16 & 5789664482 & 0.0708 & 409908245.3 & 0.0618 & 357801265,0 \\
\hline 17 & 5758956876 & 0.0600 & 345537412.6 & 0.0520 & 299465757.6 \\
\hline 18 & 5726887845 & 0.0508 & 290925902.5 & 0.0437 & 250264998.8 \\
\hline 19 & 5683380619 & 0.0431 & 245384704.7 & 0.0367 & 208580068.7 \\
\hline 20 & 5658355027 & 0.0365 & 206529958.5 & 0.0308 & 174277334.8 \\
\hline & & & 32291435677 & & 30791617625 \\
\hline & & & & & \\
\hline
\end{tabular}

Berdasarkan perhitungan Tabel 4 diatas Net Present Value atas dasar tingkat bunga $18 \%$ dan $19 \%$ sebagai berikut :

N.P.V $=18 \%$

P.V dari proceeds (dari Tabel 4)

P.V $=\sum_{t=1}^{\mathrm{n}=20} \frac{\mathrm{At}}{(1+\mathrm{i})^{\mathrm{t}}}=R p \cdot 32.291 .435 .677$

Besarnya nilai residu dari Tabel 2 adalah sebesar Rp.1.704.972.400,63

P.V dari Nilai Residu $(\mathrm{S})=\frac{s}{[1+i)^{\mid}}$atau $S(P / F, 18 \%, 20)$

$=$ Rp. $62 \cdot 231 \cdot 492,62$ 
P.V dari Investasi

$$
=\sum_{t=0}^{n=0} \frac{A t}{(1+\mathrm{i})^{\mathrm{t}}}=R p \cdot 5.006 .355 .000
$$

N.P.V = PV dari proceeds + PV dari nilai residu - PV dari investasi

$$
\begin{aligned}
& =\sum_{t=1}^{n=20} \frac{A t}{(1+i)^{t}}+\frac{S}{(1+i)^{t}}-\sum_{t=0}^{n=0} \frac{A t}{(1+i)^{t}} \\
& =\text { Rp.2.734.731.217 }
\end{aligned}
$$

NPV $=19 \%$

P.V dari proceeds (dari Tabel 4)

$=\sum_{t=1}^{n=20} \frac{A t}{(1+i)^{t}}=R p \cdot 30.791 .617 .625$

Besarnya nilai residu dari Tabel 2 adalah sebesar Rp.1.704.972.400,63

P.V dari Nilai Residu(S) $=\frac{S}{(1+1)^{3}}$ atauS $(P / F, 18 \%, 20)$

P.V dari Investasi

$$
=\text { Rp. } 52 \cdot 513 \cdot 149,93
$$

$=\sum_{t=0}^{n=0} \frac{A t}{(1+i)^{t}}=R p \cdot 5.006 .355 .000$

N.P.V 21\% = PV dari proceeds + PV dari nilai residu - PV dari investasi

$=\sum_{t=1}^{n=20} \frac{A t}{(1+i)^{t}}+\frac{s}{(1+i)^{t}}-\sum_{t=0}^{n=0} \frac{A t}{(1+i)^{t}}$

$=$ Rp.27.337.593.826,9

Internal rate of return yang sebenarnya adalah terletak tingkat bunga 20\% dan $21 \%$ dapat dihitung dengan persamaan (18).

$$
r=P 1-C 1 \frac{P 2-P 1}{C 2-C 1}
$$

Keterangan :

$$
\begin{aligned}
& \mathrm{P} 1=18 \% \mathrm{P} 2=19 \% \\
& \text { C1 = Rp.2.734.731.217 C2 = Rp.27.337.593.826,9 } \\
& r=18 \%-2.734 .731 .217 \frac{1976-1896}{27.9 a 7.592 .926,9-2.724 .791 .217} \\
& =18 \%-\frac{2.794 .791 .217}{24.602 .862 .609 .9}(\%) \\
& =18 \%+\frac{2.794 .791 .217}{24.602 .862 .609 .9}(\%) \\
& =18 \%+0,111 \% \\
& =18,111 \%
\end{aligned}
$$

Hasil dari perhitungan internal rate of return sebesar 18,111\% berarti investasi untuk kegiatan pemeliharaan dalam keadaan bertegangan dapat diterima, karena internal rate of return lebih besar dari pada rate of return (tingkat bunga pengembalian) yang dikehendaki yaitu sebesar 18\%.

\subsection{Net Benefit-Cost Ratio} 19).

Persamaan untuk menghitung Net B/C

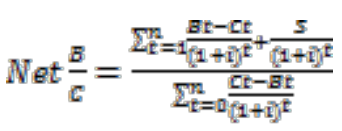

Kriteria investasi tersebut diterima apabila Net $B / C>1$ dan ditolak apabila perhitungan Net $B / C<1$.

Untuk perhitungan Net B/C Ratio maka perlu dihitung dahulu Net Present value yang dapat dilihat pada Tabel 5.

Tabel 5. Perhitungan pv investasi untuk pemeliharaan bertegangan

\begin{tabular}{|c|c|c|r|}
\hline \multirow{2}{*}{ Tahun } & $\begin{array}{c}\text { Aliran Kas } \\
\text { Masuk atau } \\
\text { proceeds }\end{array}$ & $\begin{array}{c}\text { Faktor Bunga } \\
\text { (P/F ,i\% ,n) }\end{array}$ & $\begin{array}{c}\text { Nilai sekarang } \\
\text { (PV) dari } \\
\text { Proceeds }\end{array}$ \\
\cline { 2 - 4 } & $\mathbf{( R p )}$ & $\mathbf{i = 1 8 \%}$ & $\mathbf{( R p )}$ \\
\hline 0 & -5006355000 & 1 & -5006355000 \\
\hline 1 & 6130647311 & 0.8457 & 5195723596 \\
\hline 2 & 6112958414 & 0.7182 & 4390326733 \\
\hline 3 & 6094760550 & 0.6086 & 3709271271 \\
\hline 4 & 6076009495 & 0.5158 & 3134005698 \\
\hline 5 & 6056659755 & 0.4371 & 2647365979 \\
\hline 6 & 6036664453 & 0.3704 & 2235980513 \\
\hline 7 & 6015975213 & 0.3139 & 1888414619 \\
\hline 8 & 5994542048 & 0.2660 & 1594548185 \\
\hline 9 & 5972313234 & 0.2255 & 1346756634 \\
\hline 10 & 5949235189 & 0.1911 & 1136898845 \\
\hline 11 & 5925252341 & 0.1619 & 959298354,0 \\
\hline 12 & 5900306994 & 0.1372 & 809522119.6 \\
\hline 13 & 5874339192 & 0.1163 & 683185648,0 \\
\hline 14 & 5847286570 & 0.0985 & 575957727.1 \\
\hline 15 & 5819084211 & 0.0835 & 485893531.6 \\
\hline 16 & 5789664482 & 0.0708 & 409908245.3 \\
\hline 17 & 5758956876 & 0.0600 & 345537412.6 \\
\hline 18 & 5726887845 & 0.0508 & 290925902.5 \\
\hline 19 & 5683380619 & 0.0431 & 245384704.7 \\
\hline 20 & 5658355027 & 0.0365 & 206529958.5 \\
\hline jumlah Ct-Bt Positif & & 5006355000 \\
\hline Tahun 1 s/d 20 jumlah Bt-Ct Positif & 32291435677 \\
\hline Salvage Value & & 62231492.6 \\
\hline
\end{tabular}

Maka Net B/C ratio dapat dihitung :

Dari Tabel 5 PV dari Proceeds

$$
=\sum_{t=1}^{n-20} \frac{B t-C t}{\left(1+D^{t}\right.}=R p \cdot 32.291 .435 .677
$$

Besarnya nilai residu dari Tabel 5 adalah sebesar Rp.1.704.972.400,63

$$
\begin{aligned}
\text { P.Vdari nilai Residu }(S) & =\frac{S}{(1+i)^{t}} \text { ataus }\left(\frac{P}{F}, 18 \%, 20\right) \\
& =62.231 .492,622
\end{aligned}
$$

PV dari Cost Tabel 5

$$
=\sum_{t=0}^{n=0} \frac{C t-B t}{(1+i)^{t}}=R p \cdot 5.006 .355 .000
$$

Maka perhitungan Net $\mathrm{B} / \mathrm{C}$ ratio seperti persamaan (20).

PVdariBenefit $=\sum_{\mathrm{t}=1}^{\mathrm{n}=20} \frac{B \mathrm{t}-\mathrm{Ct}}{(1+\mathrm{l})^{\mathrm{r}}}+\frac{s}{(1+\hat{\mathrm{l}})^{\mathrm{r}}}$

$$
=32.353 .667 .169,6
$$

PVdaricost $=\sum_{t=0}^{n=0} \frac{C t-B t}{(1+i)^{t}}$ 


$$
\begin{aligned}
= & \text { Rp. } 5 \cdot 006 \cdot 355.000 \\
\text { Net } \frac{B}{C} \text { Ratio } & =\frac{32.353 \cdot 667 \cdot 169,6}{5.006 \cdot 355.000}=6,462
\end{aligned}
$$

Jadi hasil perhitungan Net $B / C$ ratio 6,462 berarti lebih besar dari 1 . Usulan investasi untuk pemeliharaan bertegangan dapat diterima karena berdasarkan kriteria apabila hasil perhitungan Net B/C Ratio lebih besar dari 1 maka usulan tersebut dapat diterima dan menguntungkan.

\section{KESIMPULAN}

\subsection{Kesimpulan}

Pekerjaan pemeliharaan dalam keadaan bertegangan (PDKB) di PT PLN (persero) menguntungkan secara teknis dan ekonomis. Keuntungannya adalah dapat menyelamatkan rupiah kWh sebesar Rp.8.941.763.694, SAIDI dapat ditekan menjadi 991,8122431 menit/ pelanggan/ tahun, SAIFI menjadi 14.60000046 menit/ pelanggan/ tahun. Dari analisis evaluasi investasi peralatan dalam keadaan bertegangan diperoleh Net Present Value bernilai positif sebesar Rp.27.347.312.169 Internal rate Of Return diperoleh sebesar 18,111\%, Net Benefit Cost Ratio diperoleh 6,462 lebih besar dari 1 . sehingga sangat layak untuk dilaksanakan.

\subsection{Saran}

Perlu adanya pengembangan metode yang digunakan agar mampu lebih banyak menangani pekerjaan bertegangan khususnya di daerah-daerah sempit dengan padat penduduk.

\section{DAFTAR PUSTAKA}

[1] Y. R. Kuncoro, "GOS Generation On Sale." PT PLN (Persero) P3B Jawa Bali Bidang Operasi Sistem, Mei2015.

[2] H. Samudra, I. G. D. Arjana, and I. W. A. Wijaya, "Studi Peningkatan Kualitas Pelayanan Penyulang Menggunakan Load Break Switch (LBS) Three Way," Maj. IIm. Teknol. Elektro, vol. 15, no. 1, pp. 48-55, Jun. 2016.

[3] P. I. Waroka, Pengaruh PDKB Metode Berjarak Terhadap SAIDI SAIFI dan Kwh Jual di PT. PLN (Persero) Distribusi Bali Area Jaringan Bali Selatan. 2011.

[4] G. Clive, Pengantar Evaluasi Proyek. PT Gramedia Pustaka Utama, 1998.
[5] B. Riyanto, Dasar-Dasar Pembelanjaan Perusahaan. Yogyakarta: Badan Penerbit Gajah Mada, 2001. \\ E-Journal SPEKTRUM Vol. 4, No. 1 Juni 2017}

